\title{
Teaching Natural Sciences using Local Natural Resources through Lesson Study-Based Scientific Approach to Enhance Students' Learning Interest and Outcomes
}

\author{
Arif Didik Kurniawan ${ }^{1}$, Ari Sunandar ${ }^{1}$, and Ida Kurniawati ${ }^{1}$ \\ ${ }^{1}$ Universitas Muhammadiyah Pontianak. Indonesia \\ arif.didik@unmuhpnk.ac.id
}

\begin{abstract}
Teaching Natural Sciences classes should be done creatively using natural resources as the learning media because the interaction between teachers and students without any media and learning sources will lead to students' lack of interest and low learning outcomes. Additionally, intensive communication between teachers and students needs to be taken into consideration to maximize the teaching-learning process. This study aimed at investigating the difference and the effect of teaching Natural Sciences using local natural resources through a lesson study-based scientific approach to student interest and learning outcomes at SMP Negeri 3 Sungai Raya. This study used quasiexperimental and nonequivalent control group designs. The samples were selected using a purposive sampling technique. The instruments were tests, questionnaires, and observation. The data were statistically analyzed using U-Mann Whitney. The results of the U-Mann Whitney test showed the value of students learning outcomes was 0,000 $<0.05$ and the value of students' interest was $0,000<0.05$. Besides, the value of the Effect Size of students learning outcomes reached $73.4 \%$ and the value of the Effect Size of students learning interest was $55.4 \%$. In conclusion, students learning outcomes and learning interest increase significantly after taught using local natural resources through a lesson study-based scientific approach.
\end{abstract}

\section{Introduction}

The natural environment covers all living and non-living things occurring naturally, including natural resources. The natural environment is relatively sedentary, therefore this type of environment will be more easily recognized and learned by students (Pantiwati, 2015). The natural environment is not only found in forests and mountains but also in the school environment. The school environment 
consists of biotic and abiotic components, namely plants, animals, water, rice fields, soil, and rocks. The natural resources found in the area of SMP Negeri 3 Sungai Raya can be used as learning sources for students. Learning resources are materials used to assist students to meet the expectation for learning (Pantiwati, 2015).

Classification of Living Things is one of the materials in the Natural Sciences class of junior high school level that uses the school environment as the learning sources. However, by far, this material is considered difficult to learn by the students of SMP Negeri 3 Sungai Raya since the teaching-learning process only involved teachers' and students' interaction without any other learning sources. Ideally, the natural potential at SMP Negeri 3 may contribute significant learning resources for Natural Sciences class as it is real and provides direct interaction and natural engagement. Importantly, students can be more motivated and enthusiastic because learning sources are suitable for their needs. Slameto (2013) states that learning interest gives a great influence on learning achievement because students will not learn maximally when the learning material fails to meet their needs and interest.

Sciences class emphasizes the provision of direct experiences to develop students' competencies in comprehending the natural environment scientifically (Kemendikbud, 2014). The scientific approach in teaching Natural Sciences class is highly recommended to be implemented at SMP Negeri 3 Sungai Raya, as it has an abundance of natural resources. Also, the scientific approach triggers students to be more enthusiastic to learn the subject. Asta et al. (2015) mentioned that the scientific approach can improve student learning outcomes significantly. This is because the approach can encourage students to understand and to learn the materials on their own. In other words, the teacher's role is only as of the facilitator rather than the learning center.

However, the lack of communication among Natural Sciences teachers causes a problem in teamwork. The results of teacher interviews show that the teachers never share their ideas, lesson plan, and materials before the class. These lead to low quality of teacher preparation as the lesson plan, syllabus, and teaching needs required to be updated to improve the teaching quality. Therefore, it is important to implement lesson study-based learning (LS).

Lesson Study is an activity of classroom inquiry in which several teachers collaboratively plan, teach, observe, revise, and share the results of a single classroom. According to Prayekti and Rasyimah (2012). Lesson Study provides teachers with maximum teaching-learning activity and gives students natural exposures in learning Natural Sciences so that they are motivated and excited in learning the subject. The results of Prayekti and Rasyimah's (2012) study highlight that Lesson Study assists the teacher in involving the students in the learning activity and significantly enhance their learning achievement in Natural Sciences class. Therefore, this study aimed at investigating the difference and the influence of students' interest and outcomes after taught using local natural resources through lesson study-based scientific approach

\section{Method}

This study used quasi-experimental and non-equivalent control group designs and was conducted at SMP Negeri 3 Sungai Raya in the academic year of 2017 2018. The samples were the students of class VII F and class VII G. They were selected by using a purposive sampling method. In this study, the students of class VII F were treated as the experiment group using local natural resources through a lesson study-based scientific approach, and the students of class VII F were treated as the control group using local natural resources through lesson study-based scientific approach. The stages of the Lesson Study model were done in three stages, namely plan, do, and see.

The data collection techniques were carried out by using measurement techniques, direct observation, and questionnaires. The data collection tools were in the form of test results (pretest and posttest), observation sheets, and questionnaire sheets of learning interest. The instrument used 
consisted of learning instruments and research instruments. The instrument tests were validity, reliability, different power, and difficulty level. The validity test included content and item validity. The content validity was conducted by the lecturers and the science teachers while the item validity was done using Product Moment Correlation.

To analyze the data, particularly to test the differences in student learning outcomes and interest, this study used a statistical test of prerequisite and hypothesis analysis test with a significance level of $5 \%$. The prerequisite test was accomplished as the requirement to test the next step of hypothesis analysis. The hypothesis analysis test of the student's outcomes and learning interest was the Mann Whitney U Test.

The data analysis to test the effect of students learning outcomes and interest used Effect Size pattern, as follow (Sutrisno, 2008):

$$
\mathrm{ES}=\frac{\overline{\mathrm{X}}_{e}-\overline{\mathrm{X}}_{\mathrm{c}}}{\mathrm{S}_{c}}
$$

whereas ES: Effect Size; $\mathrm{X}^{-} \mathrm{e}$ : The mean of the Experimental group; $\mathrm{X}^{-} \mathrm{c}$ : The Mean of the Control Group; and Sc: Deviation standard of Control Class.

\section{Results and Discussion}

This is the data of students learning outcomes and interests. The data were gathered from the gain value of class VII F and class VII G students

\subsection{The differences in the students learning outcomes}

The results were based on the changes in ability after learning the subject as follows:

\begin{tabular}{lccc}
\hline Class & Pre-test & Post-test & Gain \\
\hline Experiment & 46 & 83 & 37 \\
Control & 54 & 78 & 24 \\
\hline
\end{tabular}

Table 1: The mean score of the students learning outcomes

Table 1 showed the mean score of the experiment class was higher than the control class. It was proven by the hypothesis test.

The hypothesis test of the learning outcomes was to gain valuable data or the value of the differences (posttest-pretest). In this case, the hypothesis test used the Mann Whitney U Test. Further, the Hypothesis testing used SPSS for windows 17.0 with a significance level of 5\%.

\begin{tabular}{cc}
\hline & Value \\
\hline Mann-Whitney U & 236.000 \\
Asymp. Sig. (2-tailed) & .000 \\
\hline
\end{tabular}

Table 2: The results of the hypothesis test of students learning outcomes

Table 2 showed that the hypothesis $\mathrm{H}_{\mathrm{o}}$ was rejected and Ha was accepted because of $0.00<0.05$. This proves that there were differences in learning outcomes taught using a lesson study-based scientific approach comparing those taught using local natural resources using a scientific approach. As stated by Prayekti (2012), a lesson study triggers teachers to create the maximum and the best learning process that improves student learning outcomes in a natural science subject.

In the 'Do 1' phase (observation), the teacher invited students to observe moss and ferns. During the observation, several students were busy playing with friends rather than observing. They thought 
that the activity was only a formality. As a result, they couldn't complete the observation sheet provided by the teacher. The observer highlighted that the teacher didn't guide the students during the 'See 1' phase. Therefore, the teacher needs to pay more attention to their students during the activity. In the 'Do 2' step, the teacher provided guidance and direction for students to observe and explore information about objects observed by the students. The guidance and direction were given in the form of the object being observed related to the learning material. In this stage, students were expected to develop their knowledge on their own. When they were able to find the information from the activity, their comprehension related to the materials was considered good and will give a positive effect on their learning outcomes. It is in line with Pantiwati (2015) that emphasizes meaningful learning is very important for students because the expected learning objectives can be achieved maximally.

There were still many weaknesses in the 'Do 1' phase because the questions asked by some of the students were not on the topic they were discussing. The results of the 'see' phase of meeting 1 indicated the teacher was not successfully motivated students to be more enthusiastic in observing the objects. Abidin (2016) states the 'asking' phase should be the trigger moment to encourage students to focus on the learning material. Thus, for the next 'do 2' session, the teacher should be able to motivate students to ask about the objects being observed in detail. The evaluation of the previous stage gives positive input to the second meeting of this phase. In the second meeting, the teacher has successfully motivated students to ask some questions about the object being observed. This time, the questions raised by the students covered the material of the activity. Darmadi (2012) suggests that teachers need to guide students whenever they face problems in understanding the materials. The guidance should be based on student ability and the expected goals.

In the reasoning phase of 'Do 1', the teacher didn't instruct students to use the student worksheet as the reference. Therefore, the observer recommended teacher inform this next time when they distribute the worksheet to achieve the expected goal. The use of student worksheet is supported by Trianto (2007) that the use of student worksheet can enhance students' understanding, especially in developing the basic ability following the indicator of expected learning outcomes. In the second 'do', teachers directed students to fill in the results sheet obtained by students in the observation and to use the worksheet as the reference source, so that they will get more information from the worksheet.

In the trial phase of 'do', the number of students in each group was still too big (7). As a result, they did not pay attention to the material and the discussion; they were busy talking to each other. Thus, the observer recommended the teacher to reduce the number of students in each group to 4 and to change the seating arrangement (face-to-face seating). In the second 'do', teachers directed students to work in a smaller group. Winarsih (2012) states that doing discussion in a small group can significantly enhance the learning outcomes because each student will perform his/her task seriously and effectively based on the group deal.

In the first stage of analyzing and concluding the data, students have actively participated in the discussion. Even some of them were still not confident in expressing their opinion, they have, at least, did their best. Khusniati (2012) suggests each student should have the opportunity to talk to express his/her idea, listen to other opinions, and to work together to build and to develop knowledge in a team. In other words, learning together is better than learning individually.

In the first meeting of the communicating phase, students did not pay attention to their friends who were doing presentations. The teacher also did not give any feedback to the presentation. These points, then, became the recommendation of the 'see' phase. In the second meeting of the 'do' phase, the presentation runs effectively and interactively. The teacher also informed the students about the material being discussed at the end of the presentation. Nurani (2013) states that effective learning activity is indicated by the active participation of the students. In this case is the communication between teacher and students, and between student and student. 


\subsection{The Differences in the Students' Learning Interest}

Learning interest is a sense or willingness of learning preference to a lesson/subject without any compulsion or pressure (Slameto, 2013). The results of this study were as follow:

\begin{tabular}{cc}
\hline Class & Mean Score \\
\hline Experiment & 87 \\
Control & 80 \\
\hline
\end{tabular}

Table 3: The mean score of the learning interest

Table 3 indicated that the experiment class got higher learning interest than the control class, and it's proven by the hypothesis test.

To test the hypothesis of the learning interest, this study used the mean score of the learning interest, Mann Whitney U test, and SPSS for windows 17.0 with a significance level of $5 \%$.

\begin{tabular}{cc}
\hline & Value \\
\hline Mann-Whitney U & 236.000 \\
Asymp. Sig. (2-tailed) & .000 \\
\hline
\end{tabular}

Table 4: The hypothesis of the students learning interest

Table 4 showed hypothesis $\mathrm{H}_{0}$ was rejected and $\mathrm{Ha}$ was accepted because of $0.00<0.05$. This proves that there were differences in learning interest taught using a lesson study-based scientific approach comparing those taught using local natural resources using a scientific approach.

In the first 'do' phase, the teacher invited students to observe the mosses and ferns around the school but some of them were not interested in it. In this stage, the teacher had to reprimand the students to focus on the observation activity. In the second 'do', the teacher guided the students to observe spermatophyte and the students became more focused, enjoyed, and did their observation seriously and curiously. This is in accordance with Pantiwati (2015) that learning using the surrounding environment is no longer monotonous and can reduce students' boredom.

In the questioning phase of the first 'do'. The teacher allowed students to ask questions but the students did not dare to ask and to answer the questions from the teacher. They were still passive in this stage. The observer, then, suggested the teacher approach them and told them to be more active in asking and responding to the questions.

In the second 'do', the teacher gave more attention to students so students dared to ask questions. In this case, the teacher acted to be a student, too. This method encouraged students to participate more in the Q\&A session. According to Abidin (2016), question and answer session not only develops students' curiosity, interest, and attention about the topic of the discussion but also encourages them to be more active in the discussions.

In the reasoning and trial stage of the first 'do', students ignored the task given by the teacher. They were busy talking to each other. However, in the second 'see' teacher reminded the students to do the task related to environment observation. By reminding the students, the students could be more attentive and did the task seriously. As stated by Slameto (2013) that when students are interested in the lesson, they will encourage themselves to be more disciplined and enthusiastic in learning.

In the analyzing and concluding stages of the first 'do', some students did not pay attention to the discussion. As a result, students who were seriously participated in the discussion couldn't deal with annoying students. In this case, the observer suggested the teacher manage the class effectively. Slameto (2013) claims noisy environments can easily break students' concentration and reduce the interest in the topic being learned. This is because concentration makes students more focused and attentive, especially in analyzing and concluding data within the group.

In the communicating phase of the first 'do', some students did not listen and ignored those who were doing presentations. This caused ineffective interaction. Therefore, in the second meeting, the 
teacher encouraged all students to be more active in the activity and promoted them to respond and to give reinforcement to those who were doing presentations. Hence, in the second meeting, the teacher could feel the student's enthusiasm and participation. They responded to the presenters enthusiastically and actively. Slameto (2013) indicates that someone's interest can be expressed through verbal and non-verbal actions (statements or acts) in the learning process.

\subsection{The Effect on the Students' Learning Outcomes}

The results of the Effect Size obtained the effect of learning outcomes of 1.6 which is included in the high category and gives a $73.4 \%$ effect. This shows that teaching natural sciences using local natural resources through a lesson study-based scientific approach has a major effect on student learning outcomes. This is because learning by using local natural resources in the school environment helps students easily understand the learning material as they can develop the knowledge themselves and can interact directly with their environment. According to the Ministry of education and culture (2014), the learning process that emphasizes the direct learning experience can develop competencies to scientifically and naturally explore and understand nature. Additionally, learning using local natural resources can collaborate with a scientific approach based on the 2013 curriculum.

The scientific approach is student-centered learning. The teacher only acts as a facilitator. Learning using a scientific approach helps students solve the problems. Hence, students become more active in participating in the learning process and, ultimately, their learning outcomes are improved. According to Asta (2015), the scientific approach encourages students' understanding of the material because students find their knowledge and they are also the center of the learning process. The teacher roles as the facilitator.

Teaching natural sciences using local natural resources through lesson study-based scientific approach always results in the maximum and the effective learning because when the mistakes in the learning process occur the team will thoroughly review and discuss together. The common mistakes that happen in the learning process include the way of teacher delivers the materials and the way students learn and understand the materials. Primandari (2013) supports Lesson Study as the learning model that promotes revisions and enhancement so that teachers will never stop improving their teaching quality and facilitating the learning process to give the best learning outcomes. In other words, lesson study is effective in enhancing students learning outcomes.

\subsection{The Effect on the Students' Learning Interest}

The results of the Effect Size obtained the effect of a learning interest of 1.6 which is included in the high category and gives a 55,4\% effect. This shows that teaching natural sciences using local natural resources through a lesson study-based scientific approach has a major effect on student learning interest. This is because learning by using local natural resources in the school environment helps students to overcome the boredom as they feel more enthusiastic, motivated, and engaged. Istialina (2016:65) emphasizes using the environment as the learning sources provide an interesting authentic learning atmosphere so that the learning process becomes more efficient and effective.

Scientific approach-based learning enhances student participation because the interaction between student-environment, student-teacher, and students takes place effectively. According to the Ministry of education and culture (2014: 64), the 2013 curriculum requires the implementation of scientific approaches in the learning process as students find their knowledge by observing, questioning, reasoning, trying, analyzing data, concluding, and communicating knowledge gained from the direct experience.

Teaching natural sciences using local natural resources through a lesson study-based scientific approach promotes an effective and interesting learning process as the improvement of the discussion conducted by the observers and the teacher makes students active, attentive, and involved in the 
learning process. Students become more excited and joyfully motivated in the learning because of the teacher innovation in the natural sciences class. Slameto (2013: 57) concludes that when a learning activity or learning material is demanded by students, they will endlessly learn and feel excited. Conversely, when the students do not like the learning materials, they will not learn maximally. The findings of the study prove that lesson study has a major effect on student learning. This study showed that the users of a lesson study-based scientific approach using local natural resources can improve student learning outcomes and interests to learn of a student

\section{Acknowledgments}

The authors would like to thank the principal of SMP Negeri 3 Sungai Raya for his support in this study.

\section{References}

Abidin Y. 2013. Desain Sistem Pembelajaran dalam Konteks Kurikulum 2013. In Bahasa. Bandung. Refika Aditama.

Asta RKI, Agung GAA, and Widiyana W. I. 2015. Pengaruh Pendekatan Saintifik dan Kemampuan Berpikir Kritis terhadap Hasil Belajar IPA. In Bahasa. e-Journal PGSD Universitas Pendidikan Ganesha. 3(1): 1-9.

Darmadi H. 2012. Kemampuan Dasar Mengajar. In Bahasa. Bandung : Alfabeta

Istialina. 2016. Pemanfaatan Lingkungan sebagai Sumber Belajar pada Subtema Hewan dan Tumbuhan di Lingkungan Rumahku Kelas IV SD Negeri 3 Jeumpa Kabupaten Bireuen. In Bahasa. Jurnal Ilmiah Mahasiswa Prodi PGSD. 1(1): 59-68.

Kementerian Pendidikan dan Kebudayaan. 2014. Modul Pelatihan Implementasi Kurikulum 2013. In Bahasa. Jakarta: Badan Pengembangan Sumber Daya Manusia Pendidikan dan Kebudayaan dan Penjaminan Mutu Pendidikan.

Kusniati M. 2012. Pendidikan Karakter melalui Pembelajaran IPA. In Bahasa. Jurnal Pendidikan IPA Indonesia. 1(2): 204-210.

Nurani B. 2013. Efektifitas Pembelajaran Kooperatif Model STAD terhadap Prestasi Belajar Fisika ditinjau dari Motivasi Berprestasi Siswa SMA. In Bahasa. Jurnal Pendidikan Sains. 1(1):3547.

Pantiwati Y. 2015. Pemanfaatan Lingkungan Sekolah sebagai Sumber Belajar dalam Lesson Study untuk Meningkatkan Metakognitif. In Bahasa. Jurnal BIOEDUKATIKA. 3(1): 27-32.

Prayekti and Rasyimah. 2012. Lesson Study untuk Meningkatkan Hasil Belajar Ilmu Pengetahuan Alam bagi Siswa Sekolah Dasar. In Bahasa. Jurnal Pendidikan dan Kebudayaan. 8(1): 54-68.

Primandari FVPtNi, Suhandana AG, and Yudana MI. 2013. In Bahasa. Jurnal Program Pascasarjana Universitas Pendidikan Ganesha. 4: 1-12.

Slameto. 2013. Belajar dan Faktor-Faktor yang Mempengaruhinya. In Bahasa. Jakarta : Rineka Cipta.

Sutrisno L. 2008. Review Literatur Pendidikan IPA SD. In Bahasa. Pontianak: FKIP Untan.

Trianto. 2007. Model Pembelajaran Terpadu dalam Teori dan Praktek. In Bahasa. Jakarta: Prestasi Pustaka

Winarsih A and Mulyani S. 2012. Peningkatan Profesionalisme Guru IPA melalui Lesson Study dalam Pengembangan Model Pembelajaran PBI. In Bahasa. Jurnal Pendidikan IPA Indonesia. 1(1). 43-50. 